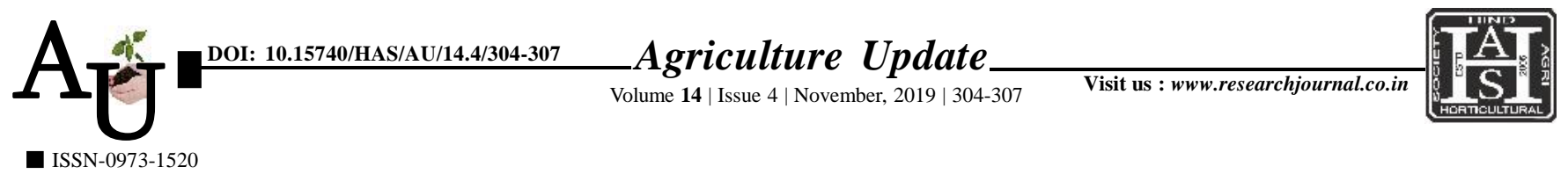

\title{
Research article: Correlates of entrepreneurial behaviour of floriculture farmers
}

Article Chronicle: Received : 19.06.2019;

Revised : 11.10.2019; Accepted : 18.10.2019

KEY Words: Entrepreneurial behaviour, Floriculture farmers

Author for correspondence :

\section{J.H. Gaikwad}

Department of Agricultural Extension, Agriculture Technology School, Puntamba, Ahmednagar (M.S.) India Email: jh_gaikwad@redif fmail.com

\section{J. H. Gaikwad}

SUMMARY : Gerbera is an exotic/ornamental flower plant grown throughout the world and known as "African Daisy" (or) "Transwal Daisy". This flower originated from Africa and Asian continents and belongs to "Compositae" family. The entrepreneurial behaviour is not necessarily doing new things but also doing things in a new way that has been already done. The entrepreneur is an economic man who strives to maximize his profits by adoption of innovations. However entrepreneurs are not simply innovators, they are mean with a will to act, to resume risk and to bring a changes through organization of human efforts. The present study was conducted in Ahmednagar District of Maharashtra State.The present study was conducted in Ahmednagar District of Maharshtra State. The present investigation aimed at knowing the Correlates of entrepreneurial behaviour of gerbera growers in Ahmednagar District of Maharashtra State. So, the exploratory research design was used for the present study. In Ahmednagar District there are three tehsil, of namely Newasa, Rahuri and Rahata was purposively selected on the basis of farmers who had the highest Gerbera production. From each of the selected tehsils, 4 villages will be randomly selected from the list of villages covered in the farmers who had the highest Gerbera production. Thus, in total 12 villages was selected for the study. Forty (40) respondents from was form three tehsils, namely: Newasa, Rahata and Rahuri in all 120 respondents was selected.The findings are as follows;Majority of the respondents $(65.00 \%)$ had medium level of entrepreneurial behaviour, whereas 15.00 per cent and 20.00 per cent of the respondents had high and low level of entrepreneurial behaviour, respectively. Majority of the respondents $(68.83 \%)$ had medium level of innovativeness, whereas 18.34 per cent had high level of innovativeness and 20.83 per cent of the respondents had low level of innovativeness.Majority of the respondents $(70.00 \%)$ had medium level of achievement motivation, whereas 11.67 per cent and 18.33per cent of the respondents had high and low level of achievement motivation, respectively. 74.16 per cent of the respondents had intermediate decision making ability.

How to cite this article : Gaikwad, J.H. (2019). Correlates of entrepreneurial behaviour of floriculture farmers. Agric. Update, 14(4): 304-307; DOI : 10.15740/HAS/AU/14.4/304-307. Copyright@ 2019: Hind Agri-Horticultural Society. 